\title{
Produksi bersih dan model kerjasama sebagai upaya mitigasi emisi gas rumah kaca pada sektor industri
}

\section{Clean production and cooperation model as a efforts to mitigate greenhouse gas emissions in the industrial sector}

\author{
Muryani \\ Departemen Ilmu Ekonomi, Fakultas Ekonomi dan Bisnis, Universitas Airlangga \\ E-mail: muryani@feb.unair.ac.id
}

\begin{abstract}
Abstrak
Pemanasan global telah menyita perhatian dunia bahkan akan semakin bertambah besar dimasa yang akan datang mengingat akibat yang ditimbulkannya UNO, melalui program lingkungan UNEP (United Nations Environment Programme) dan Organisasi Meteorologi Dunia (World Meteorological Organization, WMO) membentuk The Intergovernmental Panel on Climate Change (IPCC) pada 1988 untuk meneliti dan menganalisa isu-isu ilmu pengetahuan yang muncul. Makalah ini akan membahas tentang emisi GRK dari empat industri yaitu baja, aluminium, semen dan kimia.Guna mengantisipasi meningkatnya emisi GRK maka keempat industri ini perlu melakukan kerjasama. Model kerjasama apa yang paling tepat juga akan dibahas pada makalah ini.Selanjutnya alternatif solusi yang bisa. Ada beberapa emisi GRK dari sektor industri, mulai dari industri kimia, baja, semen dan alumunium. Dalam Protocol Kyoto, tersedia tiga mekanisme fleksibel dalam upaya pencapaian target penurunan emisi GRK, yaitu Emissions Trading (ET) atau perdagangan emisi antar negara maju, Joint Implementation (JI) atau pelaksanaan penurunan emisi secara bersama sama antar negara maju, dan Clean Development Mechanism (CDM) atau kerjasama antara negara maju dan negara berkembang. Studi ini menyimpulkan bahwa salah satu cara yang strategis untuk melindungi atmosfir adalah dengan cara mengontrol penggunaan sumber daya alam melalui emisi GRK.
\end{abstract}

Kata kunci: lingkungan; industri; kerjasama; produksi; kontrol

\begin{abstract}
Global warming has seized the world's attention even more in the future in view of the consequences caused by UNO, through the UNEP (United Nations Environment Program) and the World Meteorological Organization (WMO) to form The Intergovernmental Panel on Climate Change (Climate Change) IPCC) in 1988 to research and analyze emerging scientific issues. This paper will discuss GHG emissions from four industries, namely steel, aluminum, cement and chemicals. To anticipate the increase in GHG emissions, the four industries need to collaborate. The most appropriate model of cooperation will also be discussed in this paper. Further alternative solutions can. There are several GHG emissions from the industrial sector, ranging from the chemical industry, steel, cement and aluminum. In the Kyoto Protocol, three flexible mechanisms are available in an effort to achieve GHG emission reduction targets, namely Emissions Trading (ET) or emissions trading between developed countries, Joint Implementation (JI) or the implementation of emission reductions together between developed countries, and the Clean Development Mechanism (CDM) or cooperation between developed and developing countries. It can be concluded that one of the strategic ways to protect the atmosphere is by controlling the use of natural resources through GHG emissions.
\end{abstract}

Keywords: environment; industry; cooperation; production; control

\section{Pendahuluan}

Pemanasan global telah menyita perhatian dunia bahkan akan semakin bertambah besar dimasa yang akan datang mengingat akibat yang ditimbulkannya. UNO, melalui program lingkungan UNEP (United Nations Environment Programme) dan Organisasi Meteorologi Dunia (World Meteorological Organization, WMO) membentuk The Intergovernmental Panel on Climate Change (IPCC) pada 1988 untuk meneliti dan menganalisa isu-isu ilmu pengetahuan yang muncul. Sejak 1990 setiap lima atau enam tahun IPCC telah mengeluarkan laporan-laporan yang berkaitan dengan ilmu pengetahuan melalui pengamatan dan prediksi untuk mengetahui kecenderungannya di masa depan. 
Pemanasan global dapat didefinisikan sebagai fenomena meningkatnya suhu global dari tahun ke tahun karena terjadinya efek rumah kaca yang disebabkan oleh meningkatnya emisi gas-gas seperti karbondioksida $\left(\mathrm{CO}_{2}\right)$, metana $\left(\mathrm{CH}^{4}\right)$, dinitrooksida $\left(\mathrm{N}_{2} \mathrm{O}\right)$ dan $\mathrm{CFC}$ sehingga energi matahari terperangkap dalam atmosfer bumi (IPCC 2007).

Penyebab terbentuknya efek rumah kaca yaitu karena adnya hasil pemanasan bumi yang dilepaskan ke atmosfer, hal ini di sebut Gas Rumah Kaca (GRK) (Riebeek 2010). Efek rumah kaca ini terbentuk dikarenakan oleh meningkatnya emisi gas-gas, seperti karbondioksida (CO2), dinitrooksida (N2O), chlorofluorocarbons (CFC), metana (CH4), dan lain-lain, sehingga menyebabkan energi matahari yang masuk ke dalam atmosfer. Gas Rumah Kaca (GRK) dihasilkan dari kagiatan bisnis perusahaan, sehingga para pengusaha seharusnya memiliki tanggung jawab terhadap dampak dari pemanasan globalSebagian besar unsur yang dikeluarkan dan yang berkontribusi dalam pemanasan global ialah karbon (carbon disclosure). (Choi et al. 2013; Luo et al. 2013; Jannah dan Muid 2014; Luo dan Tang 2014; Matsumura et al. 2014; Najah 2012).Tetapi, emisi pendukung timbulnya pemanasan global bukan hanya dari unsur karbon saja, ada beberpa senyawa seperti; seperti natrium $(\mathrm{N})$, fluor $(\mathrm{F})$, dan lain-lain oleh karena itu beberapa penelitian menggunakan istilah emisi GRK (Prado-Lorenzo et al. 2009; Rankin et al. 2011). Beberapa penelitian telah menemukan dampak positif antara pengungkapan informasi emisi GRK dan kinerja kegiatan perusahaan (Matsumura et al. 2014; Clarkson et al. 2011; Al-Tuwaijri et al. 2004; Krishnan 2003; Klassen dan McLaughlin 1996).

Semakin meningkatnya konsentrasi beberapa jenis gas ini di atmosfer bumi tersebut dapat mengakibatkan penyerapan energi matahari dan radiasi panas bumi menjadi semakin tinggi (Gambar 1). Kondisi ini akan meningkatkan suhu udara di permukaan bumi. Kenaikan temperatur global termasuk Indonesia - yang terjadi pada kisaran 1,5-40 Celcius pada akhir abad 21.Efek rumah kaca (ERK) akan timbul jika konsentrasi GRK ini tidak dikendalikan keberadaannya maka dapat memicu terjadinya perubahan iklim yang lebih luas dampaknya.

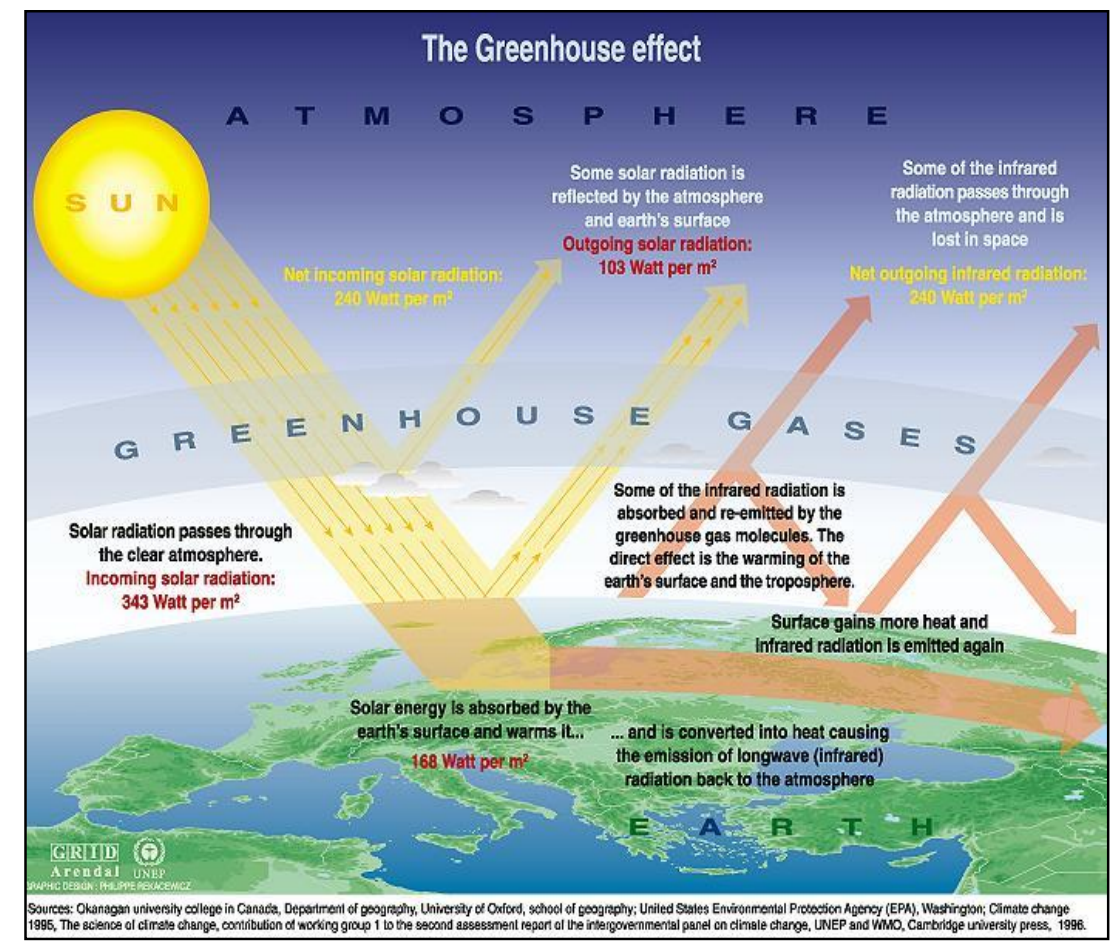

\section{Gambar 1.}

Proses terjadinya efek rumah kaca (ERK)

Global warming menyebabkan dampak yang luas bagi lingkungan bio-geofisik (contohnya melelehnya es di kutub, kenaikan permukaan laut, perluasan gurun pasir, peningkatan hujan dan banjir, perubahan iklim, punahnya flora dan fauna tertentu, migrasi fauna dan hama penyakit) sedangkan dampak bagi 
aktivitas sosial-ekonomi masyarakat meliputi (June, T. 2007) : (a) gangguan terhadap fungsi kawasan pesisir dan kota pantai, (b) gangguan terhadap fungsi prasarana dan sarana seperti jaringan jalan, pelabuhan dan bandara (c) gangguan terhadap permukiman penduduk, (d) pengurangan produktivitas lahan pertanian, (e) peningkatan resiko penyakit bagi manusia, seperti misalnya kanker kulit.

Protokol Kyoto diadakan pada Bulan Desember 1997 yang bertujuan untuk mencapai kesepakatan dalam mengurangi dampak GHG. Pertemuan ini merupakan persetujuan negara-negara industri untuk mengurangi emisi GHG secara kolektif sebesar 5,2\% sejak tahun 1990. Target Kyoto adalah pengurangan $8 \%$ untuk negara-negara Uni Eropa, 7\% untuk AS, dan 0\% untuk Rusia, dan batas penambahan emisi yang diizinkan untuk Australia sebesar 8\% dan 10\% untuk Islandia. Perkembangan dari pertemuan ini adalah hingga 3 Desember 2007, terdapat 174 negara yang telah meratifikasi protokol tersebut termasuk Kanada, Tiongkok, India, Jepang, Selandia Baru, Rusia, Australia dan 25 negara anggota Uni Eropa. Menurut protocol tersebut jenis emisi yang menjadi target pengurangan kadarnya ada enam dari 16 jenis yaitu $\mathrm{CO}_{2}, \mathrm{CH}_{4}, \mathrm{~N}_{2} \mathrm{O}$, $\mathrm{HFCs}$, PFCs dan $\mathrm{SF} 6$. Gas carbon merupakan penyebab utama dari terjadinya perubahan iklim. Penyumbang terbesar peningkatan konsentrasi emisi gas carbon disebabkan oleh kelistrikan menyumbang (42\%), Sektor transportasi menyumbang (24\%), Industri menyumbang (20\%), Kependudukan serta penggunaan barang komersial menyumbang (14\%).

Diperkirakan peningkatan pertumbuhan industri tahun 1995 hingga 2025 akan mengakibatkan peningkatan jumlah emisi GRK.Oleh karena itu perlu dilakukan studi pemilihan teknologi proses dengan beberapa scenario yang sesuai hingga tahun 2020. Semua scenario berdasarkan emisi $\mathrm{CO}_{2}$ yang jumlah diperkira meningkat terus dalam jangka pendek maupun jangka panjang. Proyeksi kenaikan emisi tergantung pada dua factor yaitu proyeksi pertumbuhan produksi industri (semen,logam,kimia dan lain lain) di dunia dan potensi proses pengurangan emisi $\mathrm{CO}_{2}$ yang limit.

Dapat diperkirakan bahwa emisi $\mathrm{CO}_{2}$ akan meningkat dua kali lipat pada 25 tahun mendatang. Implementasi efisiensi energi agar ditingkatkan dari 35 hingga $60 \%$, hal in tergantung pada kesanggupan industri dalam mengindentifikasi dan mengukurnya. Dua pilihan proses dapat diperkirakan akan menurunkan emisi $\mathrm{CO}_{2}$ dari pabrik semen dari setiap tahapan pengembangan proses. Perlu dilakukan penelitian dan pengembangan untuk pendahuluan bagi tujuan komersial.

Makalah ini akan membahas tentang emisi GRK dari empat industri yaitu baja,aluminium, semen dan kimia.Guna mengantisipasi meningkatnya emisi GRK maka keempat industri ini perlu melakukan kerjasama. Model kerjasama apa yang paling tepat juga akan dibahas pada makalah ini.Selanjutnya alternatif solusi yang bisa dipilih serta produksi bersih juga akan dipaparkan di bagian akhir makalah ini.

\section{Hasil dan Pembahasan}

\section{Emisi GRK dari Sektor Industri}

Industri kimia menghasilkan emisi sebesar 4,8\% dari emisi GHG. Jenis industri ini menyumbang emisi sebesar 23\% dari emisi hasil industri. Jenis emisi yang dihasilkan adalah terbagi dari lima sumber yaitu : pembakaran bahan bakar sebesar 51\%, panas dan elektrik sebesar 29\%, adipat-asam nitrat sebesar 8\%, HFCS sebesar 7\% dan HCFC sebesar 5\%, sebagaimana tertera pada gambar 2 (Bradley, 2007). 


\section{GHGS FROM CHEMICALS AND PETROCHEMICALS}

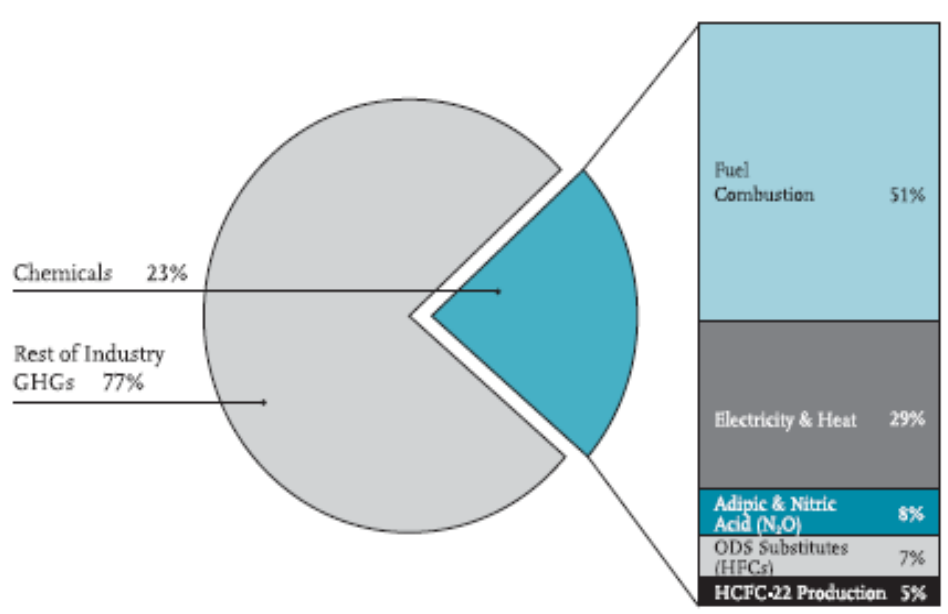

Gambar 2.

Sumber emisi dari industri kimia

Secara global industri kimia pada umumnya merupakan industri pupuk, pestisida, farmasi, plastik, resin, karet sintetis dan serta sintetis. Pendingi, cat, sabun, parfum dan produk kimia dasara seperti ethylene, propylene, and butylene. Produk industri kimia didominasi oleh 15 perusahaan terkemuka dan menguasai $20 \%$ pasar industri pada produk: farmasi , petrokimia dan produk kimia dasar. Industri ini terpusat pada Amerika Serikat, Jepang dan Cina. Sekitar 3/4 produksi kimia dunia dihasilkan di tiga negara tersebut. Sedang negara-negara Eropa memilki 31000 perusahaan yang bergerak pada industri kimia. Beberapa industri besar melakukan investasi ke negara lain seperti Industri kimia di Jerman BASF berinvestasi pada 74 negara dan Bayer pada 61 negara. Sedang di Amerika Serikat, Doe Chemical dan Du Pont masing-masing telah berinvestasi pada 32 negara.

Industri baja menghasilkan emisi 3,2 \% dari emisi GHG. Jenis industri ini menyumbang emisi sebesar $15 \%$ dari emisi hasil industri. Bentuk emisi yang dihasilkan industri ini adalah fume, oksida logam,CO, asap,debu,abu peleburan, $\mathrm{SOx}, \mathrm{Pb}$, asap , $\mathrm{Ar}$, $\mathrm{Cu}$. Emisi tersebut berasal dari pembakaran bahan bakar fosil sebesar $70 \%$ dan sebanyak $30 \%$ dari penggunaan listrik dan panas. Sebagimana tertera pada gambar 3.

\section{$\mathrm{CO}_{2}$ FROM IRON AND STEEL}

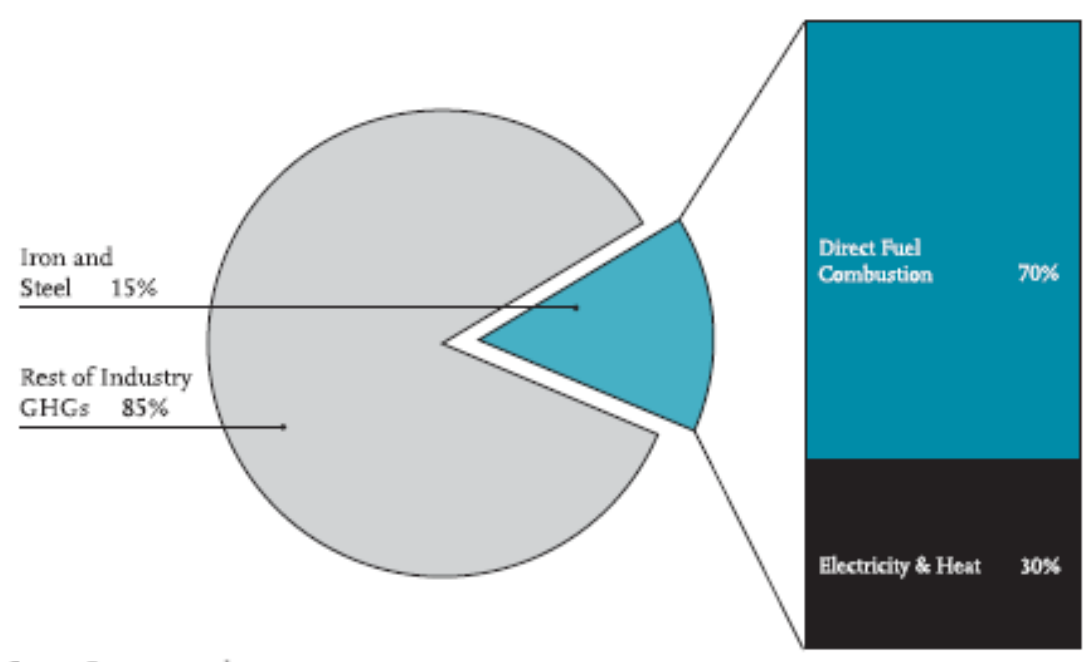

Source: Baumert et al. 2005 .

Gambar 3.

Emisi karbon dari industri baja 
Pada industri baja dunia, terdapat 12 negara yang memproduksi 90\% produksi baja dunia, sedang China, Negara-negara Eropa dan Jepang memproduksi 50\% dari total produksi dunia. Saat ini China mendominasi industri baja 35\% industri dunia. Industri baja terbesar di dunia Mittal Steel melakukan investasi pada 14 negara termasuk South Africa, Algeria, Kazakhstan, Trinidad and Tobago, Amerika Utara dan negara-negara Eropa. Sedang perusahaan baja di Jepang Nippon Steel dan POSCO tidak melakukan investasi luar negeri.

Industri semen menghasilkan emisi sebesar 3,8\% dari emisi GHG. Jenis industri ini menyumbang emisi sebesar $18 \%$ dari emisi hasil industri. Dari $18 \%$ total emisi yang dikeluarkan dari pabrik semen berupa $\mathrm{CO}_{2}$ diproduksi dari tahapan proses produksinya adalah, proses kimia dalam pembuatan batu bara (merupakan komponen utama dalam pembuatan semen (52\%), kemudian penggunaan bahan bakar fosil secara langsung (43\%) dan penggunaan BBF secara tidak langsung, yang gunakan dalam penggunaan listrik dalam proses produksinya (5\%), sebagaimana tertera pada gambar 4.

\section{GHGS FROM CEMENT MANUFACTURE}

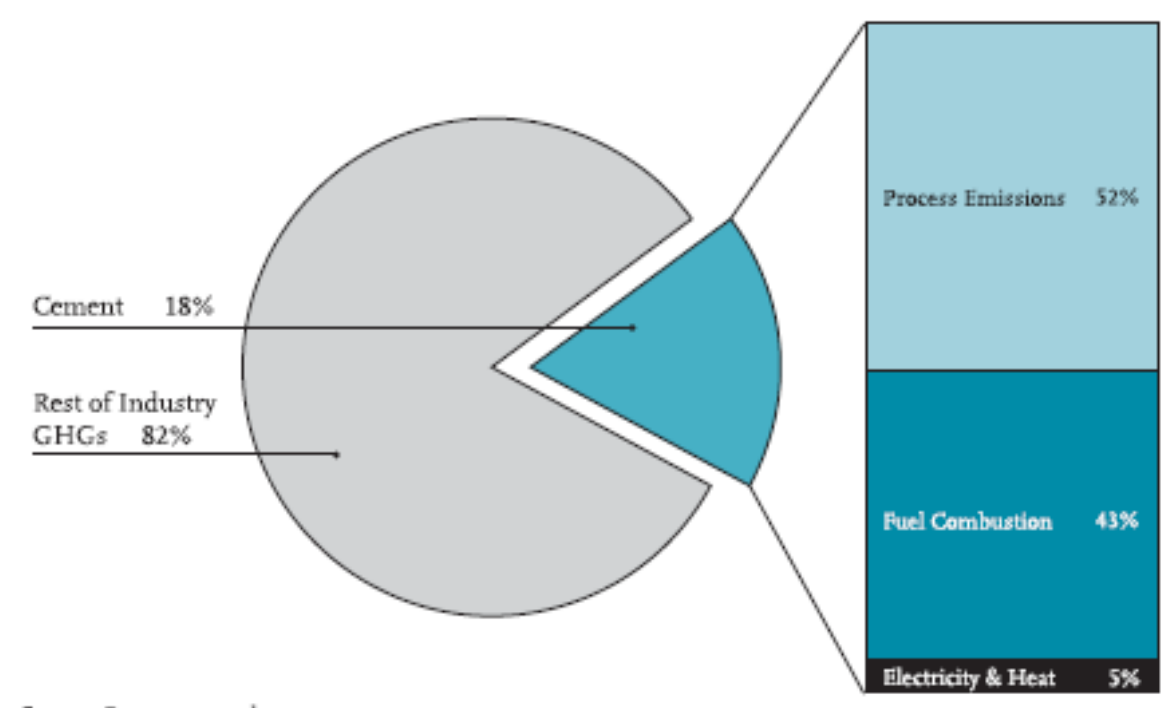

Source: Baumert et al. 2005 .

Gambar 4.

Emisi GHG dari industri semen.

Terdapat 12 negara penghasil semen terbesar menghasilkan sekitar $81 \%$ produksi semen di dunia. Cina merupakan negara penghasil semen terbesar $43 \%$ dari total produksi dunia (2004). Pertumbuhan yang cepat terjadi di Asia Tenggara dan Barat, sementara emisi semen di AS dan negara-negara timur tengah juga meningkat secara signifikan. Di Eropa, jepang dan Australia relatif konstan bahkan senderung menurun. Kerjasama dalam bentuk investasi pada industry semen cenderung mengalami peningkatan.

Sektor ini berkembang dengan adanya perusahaan multi nasional yang besar yang berinvestasi pada negara lain. Sebagai contoh, La Farge menginvestasikan pada 75 negara dan Holcim pada 70 negara. Sedang Cina dan beberapa negara berkembang lainnya memiliki peranan yang lebih kecil pada industry semen. Namun dengan meningkatnya pertumbuhan industri ini, peningkatan gas rumah kaca yang teremisi ke atmosfir akan juga meningkat, kecuali jika benar benar serius mengendalikannya.

Industri aluminium menghasilkan emisi sebesar 0,8\% dari emisi GHG. Jenis industri ini menyumbang emisi sebesar 4\% dari emisi hasil industri. Emisi tersebut bersumber dari pembakaran bahan bakar fosil, elektrikal, PFC dan emisi $\mathrm{CO}_{2}$ akibat proses smelting. Sebagian besar emisi diperoleh dari proses 
semlting yang menggunakan energi listrik sekitar $15000 \mathrm{kwh}$ per ton produksi. Sebagaimana tertera pada gambar 5 (Bradley, 2007).

\section{GHGS FROM ALUMINUM MANUFACTURE}

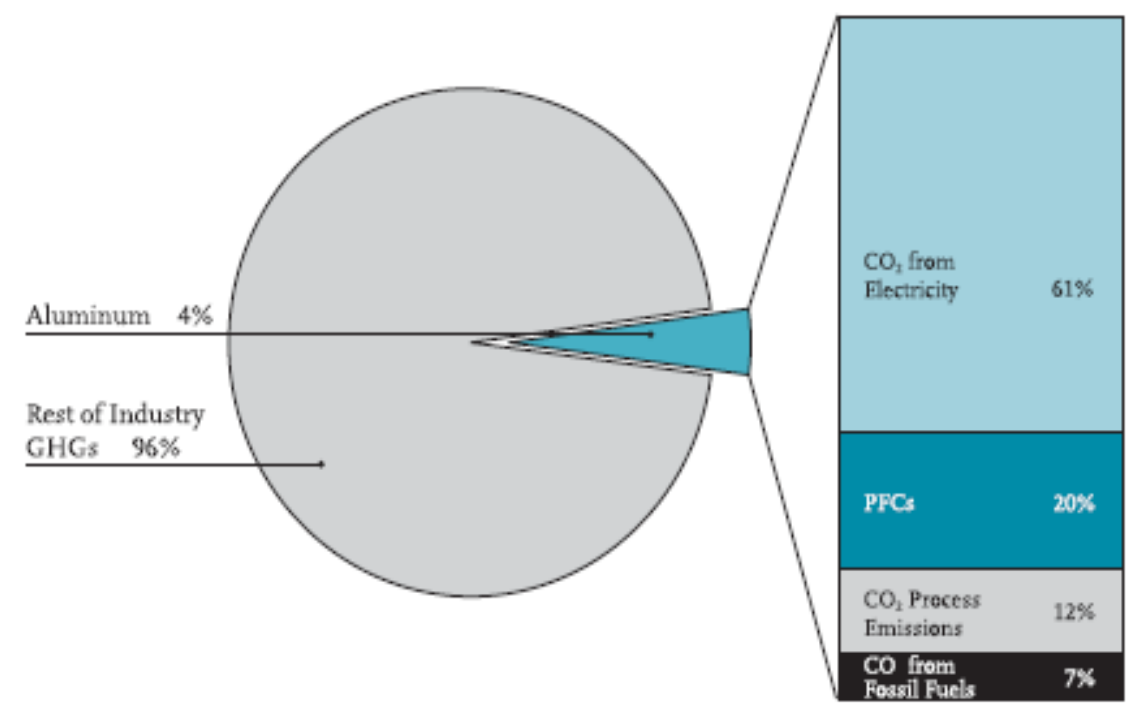

Source: Baumert et al. 2005 .

Gambar 5.

Emisi dari industri aluminium

Pada proses smelting pada umumnya menggunakan dua jenis teknologi yang diguankan yaitu Sodeberg dan Pre Bike. Selanjutnya dengan penerapan teknologi point fed dan centre worked akan mereduksi emisi PFC dan $\mathrm{CO}_{2}$. menurut survey yang dilakukan oleh IAI penerapan teknologi ini dapat mereduksi sekitar 73\% pada tahun 2003 dibandingkan tahun 1997.

Industri aluminium didominasi oleh 12 negara yang menghasilkan $82 \%$ produk dunia. China, Rusia, Uni Eropa, Canada dan Amerika Serikat menghasilkan 61\% dari total produksi. Selain itu, industri aluminium hanya didominasi oleh sejumlah perusahaan dan hanya sedikit yang merupakan perusahaan multinasional. Sepuluh perusahaan besar menghasilkan 55\% dari industri aluminium dunia. Alcan, Alcoa dan Rusal memberi kontribusi sebesar 1/3 dari produksi global. Alcan dan Alcoa merupakan perusahaan multinasional yang telah dan sedang beroperasi di 25 negara di dunia.

\section{Kerjasama sektoral untuk penurunan emisi}

Kesepakatan komprehensif untuk menurunkan emisi, Kyoto Protokol ,ternyata memunculkan banyak kesulitan didalam implementasinya, disamping juga tidak semua negara utama seperti Amerika, China, India dan Australia (ratifikasi menyusul) menyepakati perjanjian tersebut. Kerumitan kemudian muncul karena beberapa alasan, pertama, adanya kompleksitas tehnik untuk sektor tertentu, misalnya kehutanan dan industri tertentu.

Kedua, sensitivitas politik antar negara. Ketiga, masalah kompetisi untuk sektor sektor yang bergerak pada perdagangan internasional. Keempat, tantangan politik dalam melakukan dorongan persuasif pada negara berkembang untuk berpartisipasi dalam reduksi emisi. Namun kesulitan ini akan teratasi manakala tiap negar berbicara masalah kepentingan nasional mereka sendiri.melalui pendekatan kepentingan nasional ternyata lebih rasional dan mampu menyelaraskan tujuan kesepakatan global dan tujuan nasional suatu negara.hal ini lebih efisien dari pada masing masing negara bekerja secara individual untuk reduksi emisi, karena terlalu mahal. 
Atas dasar argumen ini maka berkembanglah kerjasama sektoral untuk industri industri sejenis antara negara negara yang memiliki kepentingan yang sama dan untuk mencapai strategi yang lebih efisien dalam mitigasi emisi. Dalam kenyataan banyak negara mengimplementasikan kesepakatan sektoral, karena memiliki beberapa kelebihan, diantaranya; pertama, kerjasama pada level sektoral lebih memampukan banyak negara untuk berpartisipasi pada mitigasi emisi karena lebih politically manageable. Sekalipun ada keengganan dari negara berkembang, namun dengan beradaptasi secara harmonis mereka akhirnya dapat berpartisipasi dalam perjanjian sektoral.

Kedua, melalui perjanjian sektoral kesulitan dalam persoalan aturan nasional masing masing negara agak teratasi,misalnya satu negara mendapat aturan ketat tentang GRK (misalnya industri baja)sedang negara yang lain tidak karena alasan membuka lapangan kerja.Dengan kerjasama sektoral aturan ketat disuatu negara bisa disiasati, karena menjadi ada fleksibilitas lokasi produksi antar negara yang melakukan kesepakatan.

Ketiga, kerjasama sektoral dapat membantu mecapai tujuan utama, khususnya bila masalah tehnologi diperlukan, pergerakan investasi cepat tetapi tidak cukup ada insentif untuk mitigasi emisi. Dengan merinci kegiatan menjadi berbasis sektor, akan semakin memudahkan negosiasi antar negara dan memungkinkan penyelesaian persolan emisi secara terpisah namun tetap mendukung kesepakatan global.

Upaya upaya kerjasama sektoral untuk mitigasi emisi GRK yang kreatif dapat dilakukan pada sektor industri antara lain seperti; Pertama, Efisiensi, yaitu efisiensi penggunaan sumber energi untuk proses industri sehingga dapat menghasilkan produksi yang maksimum dengan menggunakan sumber energi seminimal mungkin. Dengan demikian, diharapkan pemakaian energi seperti kayu, batu bara, gas bumi, minyak bumi, dll akan berkurang. Hal tersebut pada akhirnya dapat mengurangi penebangan hutan (deforestasi) serta mengurangi emisi gas-gas rumah kaca yang sangat berperan dalam pemanasan global.

Kedua, penggunaan energi altrenatif yang ramah lingkungan. Energi-energi alternatif seperti yang didapat dari pembangkit listrik tenaga air, angin, uap, cahaya matahari, biodesel, dan nuklir lebih baik dibandingkan dengan penggunaan bahan bakar fosil. Salah satu contoh dalam industri baja adalah penggunaan bahan bakar hasil hutan di wilayah tropis untuk mengganti penggunaan bahan bakar fosil. Upaya ini proyek European Ultra Low $\mathrm{CO}_{2}$ Steelmaking (ULCOS) yang bekerjasama dengan French Agricultural Research Centre for International Development (CIRAD) dan enghasilkan riset penggunaan biomassa berkayu yang berkelanjutan dari tanaman eucalyptus (minyak kayu putih) sebagai suatu sumber bahan bakar yang lebih bersih.

Ketiga, standardisasi pabrik dan sistem industri lainnya. Pabrik-pabrik harus memenuhi standar pabrik yang ramah lingkungan (dan bahkan menguntungkan lingkungan sekitarnya) sebelum dapat mulai beroperasi. Di Indonesia, pemerintah mengeluarkan standar baku mutu emisi bagi industri yang diatur dalam Keputusan Menteri Negara Lingkungan Hidup No. 13 Tahun 1995 Tentang Baku Mutu Emisi Sumber Tidak Bergerak

Keempat, upaya lain dalam mengurangi efek gas rumah kaca industri juga melakukan efisiensi pemakaian energi dengan melakukan tahapan perubahan atau modifikasi desain proses yang bertujuan untuk memperoleh pasokan energi. Sehingga akan menghemat penggunaan energi dalam operasionalnya. Seperti dengan mengembangkan Heat Recovery adalah system pemanfaatan energi yang dibuang untuk dipergunakan ulang pada proses lain atau process awal suatu system. Recovery sangat umum dikenal pada proses-proses yang sangat banyak dipergunakan energi seperti Petro Kimia, industri kimia, PLTU, industri tekstil, industri semen dan sebagainya. Energi yang terbuang dapat berupa flue gas / exhaust gas steam / condensed hot / cooled air, hot gas.

Kelima, pemanfaatan energi lain ini dilakukan oleh kolompok industri dengan melakukan kerjasama terhadap produk yang seragam, (seperti penggunaan WHRPG - waste heat recovery power generation pada industri semen yang dimotori oleh NEDO Jepang) mengacu pada program produk bersih . 


\section{Model Kerjasama Kegiatan Mitigasi GRK}

Dalam upaya mengurangi emisi gas rumah kaca, Protokol Kyoto melakukan penataan secara komprehensif namun belum menunjukkan aksi yang nyata. Dukungan pemerintah dari negara-negara industri belum nampak pada upaya tercapainya kerjasama tersebut, sebagaimana tertera pada tabel 1.

Tabel 1.

Upaya pengurangan emisi GHG pada berbagai sektor

\begin{tabular}{|c|c|c|c|c|c|c|c|}
\hline Sector & $\begin{array}{c}\mathrm{CHG} \\
\text { emissio } \\
\text { ns } \\
\text { issues }\end{array}$ & $\begin{array}{c}\text { Share of } \\
\text { global } \\
\text { internatio } \\
\text { nal } \\
\text { exposure }\end{array}$ & $\begin{array}{l}\text { Concentrat } \\
\text { ion of } \\
\text { actors }\end{array}$ & $\begin{array}{c}\text { Uniformity of } \\
\text { products/proc } \\
\text { ess }\end{array}$ & $\begin{array}{l}\text { Governm } \\
\text { ent role }\end{array}$ & $\begin{array}{c}\text { CHG } \\
\text { measurem } \\
\text { ent / } \\
\text { calculation } \\
\text { issues }\end{array}$ & $\begin{array}{l}\text { CHG } \\
\text { atributi } \\
\text { on }\end{array}$ \\
\hline $\begin{array}{c}\text { Electricity } \\
\text { \& Heat }\end{array}$ & $24.6 \%$ & & - & + & - & & \\
\hline Transport & $13.5 \%$ & & & & & & \\
\hline $\begin{array}{c}\text { Motor } \\
\text { vehicle } \\
\text { manufact } \\
\text { ure }\end{array}$ & $9.9 \%$ & + & + & + & + & & \\
\hline Aviation & $1.6 \%$ & + & + & + & & + & + \\
\hline Industry & $21.1 \%$ & & & & & & \\
\hline $\begin{array}{c}\text { Chemical } \\
\mathrm{s}\end{array}$ & $4.8 \%$ & + & - & - & & & + \\
\hline Cement & $3.8 \%$ & & + & + & & & \\
\hline Steel & $3.2 \%$ & + & + & + & & & + \\
\hline Aluminum & $0.8 \%$ & + & + & + & & & + \\
\hline Buildings & $15.4 \%$ & & - & - & + & & \\
\hline $\begin{array}{c}\text { Agricultur } \\
\mathrm{e}\end{array}$ & $14.9 \%$ & & - & - & - & + & \\
\hline Waste & $3.6 \%$ & & - & + & - & + & \\
\hline $\begin{array}{l}\text { Land Use } \\
\text { Change \& } \\
\text { Forestry }\end{array}$ & $18.2 \%$ & & & - & - & + & \\
\hline $\begin{array}{l}\text { Notes: } \\
\text { mutually } \\
\text { sectoral }\end{array}$ & ctors st & in do no & $\begin{array}{l}\text { ggest a ba } \\
\text { ice is mixe }\end{array}$ & $\begin{array}{l}\text { r to internatio } \\
\text { ambiguous, or }\end{array}$ & t sectoral & or are all s & $\begin{array}{l}\text { tors } \\
\text { tional } \\
\text { grade }\end{array}$ \\
\hline
\end{tabular}

Sumber: Data Pribadi.

Tabel 1 menunjukkan bahwa pada industri kimia, semen, baja dan aluminim tidak terdapat peran pemerintah. Hal ini juga nampak dari hasil pertemuan kelompok negara G20 di Jepang yang tidak memberikan hasil dokumen kerjasama pada bidang industri. Negara G20 yang terdiri dari delapan negara industri besar dan sejumlah negara ambang industri seperti Brasil, Cina, India dan Indonesia mencari solusi untuk mengurangi emisi gas rumah kaca. Selain itu, para menteri lingkungan hidup dan energi mengupayakan pembiayaan proyek energi ramah lingkungan di sejumlah negara miskin.

Upaya kesepakatan global terbentur dengan berbagai kepentingan ekonomi. Jepang dan Jerman mengusulkan agar emisi rumah kaca dibatasi melalui suatu kesepakatan yang mengikat. Jepang misalnya mendukung target penurunan emisi rumah kaca sampai setengahnya di tahun 2050. Tapi sebagian negara, terutama negara miskin dan berkembang menolak penetapan target yang mengikat bagi semua negara. Mereka menyatakan, negara maju seharusnya berbuat lebih banyak untuk mengatasi pemanasan global. Misalnya dengan membiayai proyek energi ramah lingkungan di sejumlah negara berkembang. Jepang sebagai tuan rumah pertemuan tersebut mengusulkan pembatasan emisi seharusnya diberlakukan bagi sektor industri tertentu. Misalnya produsen baja, semen dan penghasil energi. 
Sementara Cina, negara penghasil gas karbondioksida nomer dua dunia, menolak target pembatasan untuk sektor tertentu. Cina skeptis bahwa peraturan mengikat tersebut berpotensi melumpuhkan laju ekonomi Cina yang berbasis pada industri berat. Selain itu juga terdapat sandungan lain, dimana Amerika Serikat adalah satu-satunya negara industri yang belum meratifikasi Protokol Kyoto. Sehingga negara ini belum menunjukkan komitmen yang baik pada upaya pengurangan emisi. Namun demikian, kerjasama antar perusahaan sudah dilakukan pada sektor industri. Kerjasama internasional pada sector industry semen telah banyak dilakukan. Kerjasama ini diorganisir oleh the World Business Council for Sustainable Development's Cement Sustainability Initiative (CSI) yang terdiri atas 16 perusahaan dan $50 \%$ dari total industry di dunia kecuali Cina.

Upaya yang dilakukan berupa "proteksi iklim dan manajemen $\mathrm{CO}_{2}$ " terhadap negara-negara yang terlibat dalam protocol Kyoto dan sekaligus melakukan monitoring dan laporan besarnya emisi $\mathrm{CO}_{2}$ yang dikeluarkan dari industry semen. Grup ini sering kali melakukan investigasi terhadap "kebijakan publik dan mekanisme pasar emisi $\mathrm{CO}_{2}$ yang dihasilkan "meskipun tidak ada inisiatif dan target yang telah diadopsi. Industri semen yang berskala lokal juga diharapkan berkembang dengan dukung perusahaan multinasional. Ketidakpastian jumlah emisi di negara berkembang pada masa mendatang cenderung mengalami peningkatan. Standar emisi $\mathrm{CO}_{2}$ pada industri semen di US sekitar 1 ton $\mathrm{CO}_{2}$ per ton semen dan di Jepang sekitar 0,72 ton $\mathrm{CO}_{2}$ per ton semen. Sementara itu Jepang memiliki teknologi industry semen yang mampu mereduksi $35 \%$ emisi.

Pada sektor industri kimia, kerjasama antar negara belum nampak, dimana belum terdapat organisasi yang melakukan pengaturan terhadap industri ini. Pada industri baja, kerjasama secara global diatur oleh ISSI (International Iron and Steel Institute) yang beranggotakan 190 negara dengan produksi 60\% dunia. Kegiatan yang dilakukan adalah meningkatkan efisiensi energi, mengkaji teknologi yang yang mereduksi emisi $\mathrm{CO}_{2}$ per unit produksi., meningkatkan kualitas produksi, melakukan kerjasama antara IISI dengan pemerintah.

Selain itu, negara-negara Uni Eropa membentuk ULCOS (Ultra Low $\mathrm{CO}_{2}$ steel making) yang berfokus pada riset R\&D. Proyek ini melakukan riset untuk memperoleh teknologi yang dapat mengurangi emisi $\mathrm{CO}_{2}$ hingga 50\% dibawah emisi hasil tungku modern. Pada tahun 2005, telah digagas kerjasama antara industri Jepang dan China, Dimana pihak industri Jepang menyediakan teknologi untuk mereduksi emisi yang akan dimanfaatkan oleh 180 pabrik baja di Cina. Hal ini dilakukan oleh Jepang untuk memangkas emisi gas buang enam persen sampai 2012 dari level tahun 1990. Meskipun demikian, 11 dari 30 sektor industri di Jepang, termasuk baja, memiliki resiko gagal utuk memenuhi target melaksanakan sendiri pemangkasan emisi carbon dioxide untuk membantu negara memenuhi target dalam Protokol Kyoto.

Industri aluminium dunia diatur oleh lembaga IAI (The International Aluminium Institute) yang beranggotakan 26 perusahaan yang menghasilkan $80 \%$ dari produksi alumunium global. Target organisasi ini adalah mereduksi $80 \% \mathrm{PFc} /$ ton produksi Aluminium dan reduksi $10 \%$ penggunaan energi pada proses smelting. Kedua target diatas diharapkan tercapai tahun 2010 (sudah dimulai dari tahun 1990). Dari uraian di atas, maka nampak bahwa keempat jenis industri ini dapat mengembangkan kerjasama dengan model complementary. Sebagaimana tertera pada gambar 6.

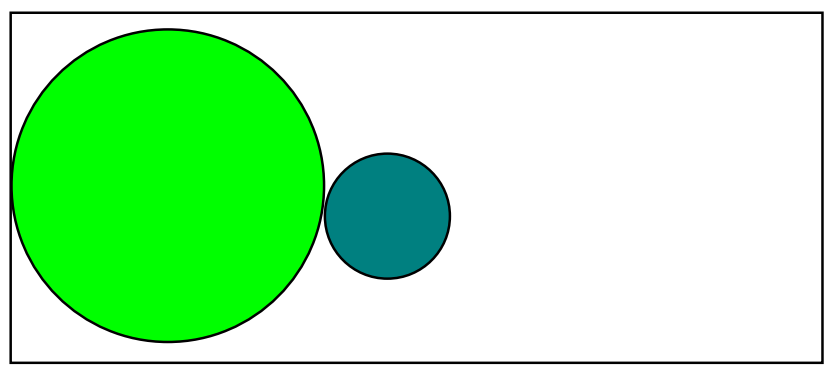

Gambar 6.

Complementary model 
Pada jenis kerjasama model komplementer ,sektor tertentu dapat terakomodir oleh dua kerjasama atau kesepakatan yang berbeda secara simultan (global dan khusus), tetapi bersifat saling melengkapi. Satu kesepakatan merupakan kesepakan komprehensif atau global yang meliputi semua sektor summber emisi seperti kyoto protocol atau UNFCC sedangkan kesepakatan yang bersifat melengkapi bisa merupakan sektor spesifik yang bersifat menyempurnakan kesepakatan global.

Tujuan dari perjanjian ini untuk mengatasi keterbatasan perjanjian global yang pada kenyataannya tidak mampu mengakomodir semua negara negara utama didunia seperti misalnya China dan India. Dua negara ini kurang sepakat dengan batasan emisi (emission caps). Model ini dapat membuka peluang untuk negara negara yang tidak sepakat pada perjanjian global, untuk pada akhirnya berminat berpartisipasi menurunkan emisi dunia melalui berbagai kesepakatan yang kretif seperti misalnya konservasi energi untuk sektor industri (khususnya kimia, aluminium, semen dan baja, peningkatan standar efisiensi dan penggantian tehnologi yang lebih environmentaly friendly.

Untuk empat jenis industri ini bersifat rigid dalam hal menurunkan emisi dikarenakan menelan biaya yang relatif besar.Oleh karena itu akan sulit mengikuti ketentuan kesepakatan global, tetapi akan teratasi melalui perjanjian dan kesepakatan yang bersifat khusus (komplementer). Kerjasama model komplementer dalam rangka untuk menurunkan emisi sangat fleksibel untuk diterapkan karena tidak harus dilakukan antar government ( $\mathrm{G}$ to $\mathrm{G})$. Kerjasama ini bisa dilakukan secara kreatif antara privat dengan privat pada sektor industri yang sama antar negara.

Kesepakatan ini bisa diwujudkan dengan negara lain dengan berbagai opsi mekanisme.Kesepakatan yang bisa dilakukan antara negara berkembang dan maju untuk menurunkan emisi salah satunya adalah CDM. Dari berbagai mekanisme pengurangan emisi GRK, CDM merupakan pilihan yang paling rasional untuk dapat diterapkan di Indonesia. Program ini dapat mengatasi mkeuangan dalam penerapan teknologi bersih lingkungan melalui program penggantian teknologi atau program modifikasi teknologi.

\section{Proyek CDM di bidang industri}

Mekanisme program penerapan CDM mendapat dukungan dari suatu Badan/Institusi. Nama Badan tersebut adalah Indonesian Committee for Climate Change (ICCC) dan diharapkan Badan tersebut independen. Badan tersebut mempunyai beberapa fungsi yang umumnya membantu industri untuk melaksanakan program CDM dan mengontrol emisi GRK di Indonesia. ICCC merupakan kelompok kerja yang dapat melaksanakan program pengurangan emisi GRK. Beberapa program yang menarik adalah tawaran untuk mempercepat penerapan teknologi bersih melalui program CDM, seperti insentif pajak, kredit dengan bunga rendah dan lain-lain.

Beberapa alternatif opsi bagi CDM sektor industri adalah, Penggantian bahan bakar dengan bahan bakar beremisi GRK rendah. Efisien pemanfaatan bahan bakar \& bahan baku per unit output. Pemanfaatan teknologi pengolahan yang lebih bersih dan emisi GRK rendah, misalnya penggantian proses pada produksi semen.

Meskipun belum diputuskan, pada dasarnya CDM dapat dilakukan dengan tiga cara (dikenal sebagai CDM architecture), yaitu : Pertama, Bilateral CDM - pelaksanaan CDM antara satu negara Annex I dan satu negara berkembang. Pada umumnya CDM ini dilakukan dalam bentuk investasi asing yang besarnya setara dengan potensi reduksi emisi GRK yang dapat dihasilkan oleh kegiatan tersebut. Investasi asing yang dihitung sebagai CDM hanya berdasarkan pada CER yang dapat dihasilkan. Kedua, Multilateral CDM - dengan mekanisme yang serupa dengan Bilateral CDM tetapi berlangsung tidak antara satu negara Annex I dan satu negara berkembang, melainkan antara beberapa negara Annex I dengan beberapa negara berkembang melalui sebuah lembaga "clearinghouse". Ketiga, Unilateral CDM - pelaksanaan kegiatan yang memiliki potensi reduksi emisi GRK dibiayai dengan investasi domestik. Pada gilirannya, investor dalam negeri ini akan mendapatkan CER yang nantinya dapat ia jual kepada negara Annex I. 
Sektor energi dalam hal ini adalah kegiatan yang menghasilkan energi. Kegiatan yang dapat dijadikan proyek CDM sektor energi adalah kegiatan yang dapat menghasilkan energi dengan emisi GRK lebih rendah dibandingkan dengan proses produksi energi yang telah digunakan (Panjiwibowo dkk, 2008). Beberapa kegiatan yang termasuk dalam sektor energi ini adalah pertama, energi terbarukan pembangkitan listrik dengan sumber energi terbarukan termasuk dalam kategori ini, misalnya saja pembangkitan listrik yang menggunakan tenaga panas bumi, tenaga air skala mikro, tenaga angin, tenaga surya serta biomasa. Energi terbarukan mengemisikan GRK yang jauh lebih kecil jika dibandingkan dengan energi fosil seperti batubara, minyak bumi serta gas bumi.

Kedua, Energi efisiensi di sisi pengadaan - proses pembangkitan listrik yang lebih efisien atau dengan teknologi yang lebih bersih termasuk di dalamnya, misalnya dengan sistem cogeneration, yang akan meningkatkan efisiensi sebanyak 50 persen. Ketiga, Pemanfaatan flare gas - gas sisa dari proses penambangan dan pengolahan minyak dan gas bumi biasanya dibakar dan dikenal sebagai flare gas. Proses pembakaran gas ini pun akan memberikan emisi GRK tambahan, karenanya flare gas harus dimanfaatkan dan tidak lagi dibakar, sehingga dalam proses pun akan terjadi efisiensi, sementara dampak terhadap lingkungan pun akan berkurang. Satu hal yang telah disepakati, pembangkit listrik tenaga nuklir walaupun dikenal sebagai zero emission (emisi GRK-nya tidak ada) tidak dapat diterima sebagai kegiatan CDM. Pertimbangan bagi hal ini lebih bersifat jangka panjang mengingat permasalahan dengan sampah nuklir yang dihasilkan.

\section{Siklus Proyek CDM di Bidang Industri}

Dalam melaksanakan proyek CDM di bidang industri terdapat beberapa tahapan yang harus ditempuh agar kegiatan yang bersangkutan dapat diterima sebagai proyek CDM di bidang industri. Tahapantahapan yang dikenal sebagai siklus proyek CDM ini adalah: pertama, identifikasi proyek - langkah pertama yang harus dilakukan adalah melakukan identifikasi apakah rencana kegiatan tersebut memiliki potensi untuk menurunkan emisi GRK atau menyerap GRK dari atmosfer. Dalam hal ini, pengusul proyek perlu melakukan penghitungan potensi penurunan ataupun penyerapan GRK. Kedua, desain proyek. Langkah berikutnya adalah pengumpulan informasi yang diperlukan dalam menyiapkan dokumen rancangan proyek (Project Design Document, PDD). Informasi yang diperlukan antara lain adalah mengenai deskripsi proyek, batasan proyek, penentuan baseline (keadaan tanpa adanya proyek tersebut) dan informasi mengenai sumber pendanaan.

Ketiga, dokumen Rancangan Proyek/Project Design Dokumen (PDD) selanjutnya, pemilik proyek menyiapkan dokumen proyek yang berisi informasi lengkap mengenai proyek serta sisi ke-CDM-annya. Beberapa hal yang harus tercantum dalam dokumen tersebut antara lain; Deskripsi umum proyek, berisi tentang tujuan proyek, deskripsi teknis proyek serta gambaran batasan-batasan proyek (project boundaries); Perhitungan emisi baseline dan metodologi perhitungannya; Perhitungan emisi proyek dan metodologi perhitungannya; Perioda waktu aktivitas proyek; Metodologi dan rencana pengawasan proyek (monitoring plan); Analisis mengenai dampak lingkungan (AMDAL); komentar publik mengenai proyek tersebut.

Keempat, persetujuan oleh Otoritas CDM Nasional (DNA) - setelah PDD selesai dibuat dan dilampiri semua informasi yang dibutuhkan, kemudian PDD diserahkan ke Otoritas CDM Nasional untuk disetujui. Setelah dinilai dan dievaluasi berdasarkan semua informasi yang tertera di dalamnya, terutama sumbangannya untuk pembangunan berkelanjutan, transparansi, dan partisipasi masyarakat, DNA akan memberikan persetujuannya. Kelima, validasi pada tahap ini, seluruh informasi yang terdapat di dalam PDD, terutama penghitungan baseline divalidasi oleh validator independen (Operational Entity, OE) yang telah diakreditasi oleh Badan CDM Internasional (CDM-Executive Board). Badan independen ini akan mengevaluasi apakah proyek tersebut telah memenuhi persyaratan CDM dan apakah proyek perhitungan CER yang dilakukan dapat diterima.

Keenam, registrasi proyek CDM harus didaftarkan ke CDM Executive Board (EB). Tahap ini dinamakan registrasi, dimana EB menerima secara formal pengajuan PDD dari kandidat proyek CDM. EB merupakan badan internasional di bawah COP/MOP, atau pertemuan tahunan para negara yang 
telah meratifikasi Protokol Kyoto, yang tugasnya adalah mengatur dan mengawasi pelaksanaan CDM di seluruh dunia. Sebuah proyek yang didaftarkan ke EB akan melalui sebuah proses komentar publik selama 30 hari, dimana PDD akan ditaruh di website EB untuk mendapatkan komentar terbuka dari semua pihak. Jika ada keberatan dari EB atau dari pihak yang terlibat dalam kegiatan proyek mengenai dokumen yang diserahkan, maka EB akan melakukan kajian yang lebih mendalam mengenai proyek yang diajukan. Jika tidak ada keberatan dari EB, maka proses registrasi akan selesai dalam waktu 8 minggu.

Ketujuh, implementasi. Tahapan dimana proyek CDM dijalankan biasanya dinamakan implementasi yang pada dasarnya dapat dilakukan sebelum registrasi maupun sesudahnya. Jika dilakukan sebelum registrasi, batas waktu paling awal adalah tahun 2000, artinya hanya proyek yang berjalan sejak tahun 2000 saja yang dapat diajukan sebagai proyek CDM. Kedelapan, Pengawasan/monitoring - setelah proyek ini didaftarkan dan diimplementasikan, maka pemilik proyek bertanggung jawab atas pengawasan atau monitoring atas penurunan emisi GRK maupun penyerapan GRK akibat adanya proyek yang bersangkutan. Pelaksanaannya sendiri harus sesuai dengan rencana pengawasan yang tertera pada PDD dan dilakukan oleh monitor independen. Kegiatan pengawasan meliputi kegiatan pengumpulan dan penyimpanan data-data yang digunakan untuk menghitung emisi baseline dan emisi proyek.

Kesembilan, verifikasi - pada tahap ini hasil pengawasan akan dikaji ulang, termasuk metodologi yang digunakan dalam melakukan pengawasan, dan kemudian dilaporkan secara tertulis. Jumlah emisi GRK yang berhasil diturunkan harus tertera di dalamnya sehingga dapat dilihat apakah penurunan ataupun penyerapan GRK yang diperkirakan telah terpenuhi. Laporan pengawasan yang dilakukan oleh badan independen ini harus dipublikasikan sebagai proses keterlibatan publik. Kesepuluh, sertifikasi penurunan emisi - sertifikasi adalah jaminan tertulis oleh badan independen yang menyatakan bahwa proyek yang bersangkutan, dalam perioda tertentu, telah berhasil menurunkan emisi gas rumah kaca sebagaimana yang telah diverifikasi. Kesebelas, penerbitan penurunan emisi tersertifikasi/Certified Emission Reduction (CER) - CDM Executive Board mempunyai waktu maksimal 15 hari setelah permohonan penerbitan CER diberikan untuk mengkaji ulang surat sertifikasi proyek yang bersangkutan. Setelah itu Executive Board harus segera mengumumkan hasilnya dan mempublikasikan keputusannya sehubungan dengan disetujui atau tidaknya CER yang diusulkan beserta alasannya.

\section{Mitigasi Emisi GRK pada Sektor Industri di Indonesia}

\section{Kerjasama masyarakat, industriawan dan Pemerintah}

Keikutsertaan masyarakat, industriawan, dan pemerintah dalam mengurangi emisi GRK adalah langkah yang paling efektif dalam menurunkan efek GRK. Pemerintah dapat menerapkan konsep pollution tax dan incentif fund; pollution tax (pajak emisi) diberlakukan untuk industri yang mengeluarkan emisi tanpa pengolahan; sedangkan incentif fund adalah bantuan biaya remediasi lingkungan untuk industri yang telah menerapkan produksi bersih (Noordwijk, 2008). Keterpaduan kerjasama pemerintah, industri dan masyarakat dapat dilihat pada Gambar 7. 


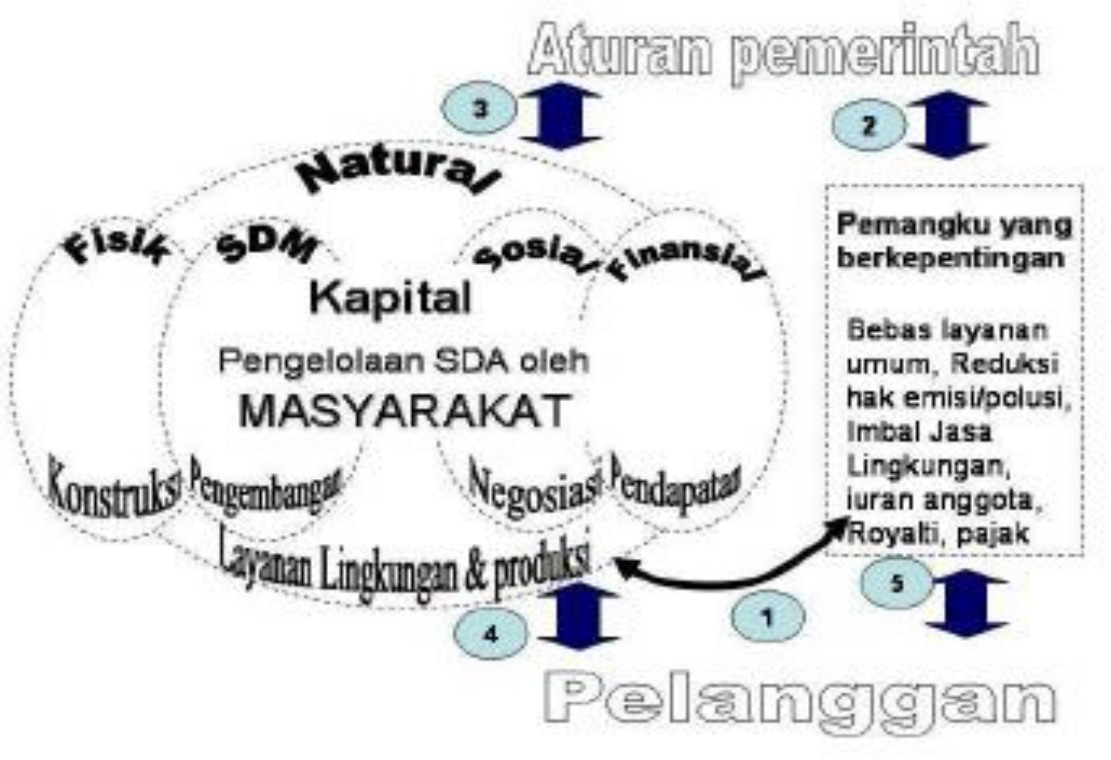

Gambar 7.

Kerjasama pemerintah dan masyarakat dalam menurunkan emisi

\section{Penggunaan Bahan bakar Nabati bagi Industri}

Emisi GRK dari sektor industri dapat dibedakan menjadi emisi dari proses pembangkitan (listrik maupun uap panas), serta emisi spesifik dari proses industri itu sendiri (misalnya emisi $\mathrm{CH} 4$ dari industri petrokimia) (Murdiyarso, 2007).Emisi $\mathrm{CO}_{2}$ dapat berasal dari pembakaran bahan bakar fosil, seperti:batubara, minyak bumi dan gas bumi, emisi dari industri semen dan konversi lahan. Berdasarkan data dari Carbon Dioxide Information Analysis Center (2000) penggunaan bahan bakar fosil merupakan sumber utama emisi $\mathrm{CO}_{2}$ didunia dan mencapai $74 \%$ dari total emisi ( Suara Karya 2007). Konversi lahan mempunyai kontribusi sebesar $24 \%$ dan industri semen sebesar 3\%. Emisi $\mathrm{CO}_{2}$ merupakan bagian terbesar dari emisi Gas Rumah Kaca (GRK) di Indonesia denganpangsa sebesar hampir 70\% sedangkan gas lainnya sebesar $30 \%$.Berdasarkan laporan Komunikasi Nasional Pertama, sumber utama emisi GRK adalah sektor energi dan sektor kehutanan. Sektor energi mempunyai pangsa sebesar $46 \%$ dari total emisi GRK yang berasal dari penggunaan bahan bakar fosil pada bermacam-macam aktivitas seperti: produksi energi, pengolahan energi dan juga pembakaran energi yang digunakan baik untuk pembangkit listrik maupun untuk keperluan industri lainnya.

Konsumsi energi komersial di Indonesia terus mengalami peningkatan dari 218,2 juta Setara Barel Minyak (SBM) pada tahun 1990 menjadi 546,6 juta SBM pada tahun 2005 atau meningkat sebesar $6,3 \%$ per tahun. Berdasarkan jenis energinya, konsumsi Bahan Bakar Minyak (BBM) merupakan konsumsi energi komersial terbesar. Sebagian besar konsumsi BBM ini digunakan untuk sektor transportasi. Peningkatan konsumsi BBM ini membebani anggaran pemerintah dalam pemberian subsidi. Beban tersebut akan terus meningkat seiring dengan kenaikan harga minyak dunia karena pemerintah masih harus mengimpor sebagian BBM untuk memenuhi kebutuhan dalam negeri. Pemanfaatan Bahan Bakar Nabati (BBN) atau biofuel sebagai sumber energi yang dapat diperbaharui dapat merupakan salah satu pilihan untuk membantu mengatasi besarnya tekanan kebutuhan BBM terutama minyak diesel dan minyak solar.

Pemerintah melalui Peraturan Presiden No.5 tahun 2006 mengeluarkan kebijakan energi nasional (Fahmi, 2008). Kebijakan ini bertujuan untuk mewujudkan keamanan pasokan energi dalam negeri. Kebijakan utama meliputi penyediaan energi yang optimal, pemanfaatan energi yang efisien, penetapan harga energi ke arah harga keekonomian dan pelestarian lingkungan. Kebijakan ini juga memuat target pencapaian bauran energi (energy mix) sampai tahun 2025 seperti ditunjukkan pada Gambar 8. 


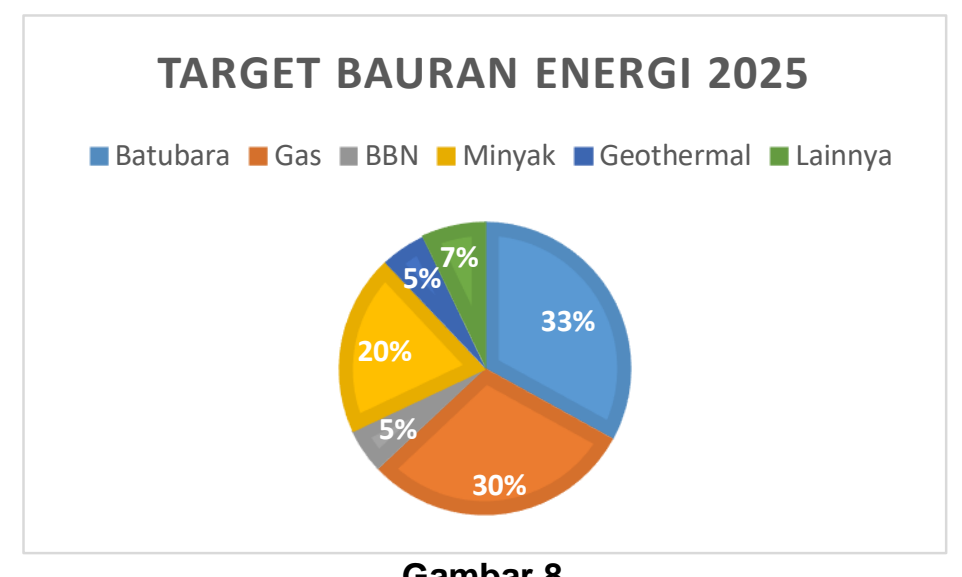

Gambar 8.

Target bauran energi 2025

Kebijakan ini diikuti dengan dikeluarkannya Instruksi Presiden No.1 Tahun 2006 tentang penyediaan dan pemanfaatan BBN sebagai bahan bakar lain dan ditindaklanjuti dengan pembentukan Tim Nasional Pengembangan Bahan Bakar Nabati (BBN) untuk Percepatan Pengurangan Kemiskinan dan Pengangguran melalui Keputusan Presiden No. 10 Tahun 2006. Tim nasional ini berkewajiban untuk menyusun Blue Print dan Road Map Pengembangan BBN. Disamping kebijakan tersebut di atas, Presiden mencanangkan Indonesia Green Energy Action Plan. Pengembangan green energy atau energi yang berbahan baku nabati mempunyai tiga aspek penting yang diyakini dapat mendorong perekonomian nasional, yaitu; Pro Jobs untuk membuka lapangan kerja yang lebih luas; Pro Growth yang dapat meningkatkan pertumbuhan ekonomi, dan Pro Poor yang akan mengurangi tingkat kemiskinan.

BBN merupakan salah satu bentuk green energy yang secara garis besar dapat dikelompokkan menjadi tiga, yaitu pertama, biodiesel merupakan bentuk ester dari minyak nabati. Bahan baku dapat berasal dari kelapa sawit, jarak pagar, kedelai dan kelapa. Dalam pemanfaatanya dicampur dengan minyak solar dengan perbandingan tertentu. B5 merupakan campuran 5\% biodiesel dengan 95\% minyak solar yang dijual secara komersiil oleh Pertamina dengan nama dagang biosolar. Kedua, bioetanol merupakan anhydrous alkohol yang berasal dari fermentasi tetes tebu, singkong, jagung atau sagu. Bioetanol dimanfaatkan untuk mengurangi konsumsi premium. E5 merupakan campuran 5\% bioetanol dengan 95\% premium yang telah dipasarkan Pertamina dengan nama dagang biopremium. Penggunaan bioetanol sampai dengan E15 tidak perlu melakukan modifikasi mesin kendaraan yang sudah ada, tetapi untuk E100 hanya dapat digunakan untuk mobil jenis FFV (flexible fuel vehicle) (Sugiyono, 2008). Ketiga, PPO merupakan minyak nabati murni tanpa perubahan sifat kimiawi dan dimanfaatkan secara langsung untuk mengurangi konsumsi solar industri, minyak diesel, minyak tanah dan minyak bakar. O15 merupakan campuran 15\% PPO dengan 85\% minyak diesel dan dapat digunakan tanpa tambahan peralatan khusus untuk bahan bakar peralatan industri. Pemakaian yang lebih besar dari $\mathrm{O} 15$ harus menambah peralatan konverter.

Potensi Pengurangan Emisi Dengan penerapan Bahan bakar nabati. Biodiesel merupakan bahan bakar alternatif yang ramah lingkungan karena tidak menimbulkan emisi polutan yang berbahaya terhadap kesehatan. Penggunaan biodiesel sebagai bahan bakar kendaraan bermotor dapat menurunkan emisi bila dibandingkan dengan penggunaan minyak solar. Biodiesel terbuat dari minyak nabati yang berasal dari sumber daya yang dapat diperbaharui. Pertimbangan lain untuk penggembangkan biodiesel adalah makin tingginya harga minyak bumi dan untuk mengurangi emisi GRK.

Dari sisi hilir, teknologi pengolahan biodiesel terus dikembangkan dan secara nasional sudah dapat dikuasai rancang bangun industri pengolahan biodiesel. BPPT telah mendisain dan membangun pabrik biodiesel dengan kapasitas 1,5 ton per hari sebagai prototipe pada tahun 2000. Prototipe ini kemudian dikembangkan lagi dan bersama dengan Pemda Provinsi Riau mendirikan pabrik biodiesel dengan kapasitas 8 ton per hari tipe batch. Pada tahun 2006 didirikan pilot plant pabrik biodiesel skala 3 ton/hari tipe kontinu berlokasi di Puspiptek, Serpong. Detail disain pabrik biodiesel skala komersial 80 ton per 
hari sudah dapat diselesaikan pada tahun 2007. Disamping BPPT, institusi lain seperti Lemigas, ITB, Departemen Pertanian, LIPI, PT. Rekin, dan beberapa perusahaan swasta, seperti PT. Energy Alternative Indonesia (EAI) dan PT. Eterindo Wahanatama juga mengembangkan pabrik biodiesel yang tersebar di berbagai wilayah Indonesia.

Untuk mengetahui potensi pengurangan emisi GRK dari pemanfaatan BBN maka harus diperhitungkan besarnya penggunaan BBM yang dapat disubstitusi dengan menggunakan BBN. Dasar untuk perhitungan emisi GRK yang sering digunakan adalah Revised 1996 IPCC Guidelines for National Greenhouse Gas Inventories dan Revised 2006 IPCC Guidelines for National Greenhouse Gas Inventories.

Berdasarkan 2006 IPCC Guidelines maka penggunaan BBN tidak dihitung emisi $\mathrm{CO}_{2}$ tetapi dicantumkan dalam bagian sendiri karena biomasa yang digunakan untuk BBN ini sudah dihitung emisinya dalam sektor Agriculture, Forestry and Other Land Use (AFOLU). Emisi GRK dari penggunaan BBN dianggap nol bila berasal dari perkebunan yang dikelola secara berkesinambungan. Perhitungan disini menggunakan pendekatan Tier 1 yang berdasarkan basis bahan bakar. Emisi yang ditimbulkan dari semua sumber pembakaran dapat dihitung berdasarkan kuantitas bahan bakar dan faktor emisi rata-rata. Dengan pendekatan ini, emisi $\mathrm{CO}_{2}$ dihitung dengan menggunakan rumus:

$$
\text { Ewisi - Z(Fud, MFF }
$$

Keterangan :

Emisi $=$ Emisi $\mathrm{CO}_{2}$ dalam $(\mathrm{kg})$

Fuela = Kuantitas Bahan Bakar (TJ)

$\mathrm{EFa} \quad=$ Faktor Emisi $(\mathrm{kg} / \mathrm{TJ})$

a = Jenis Bahan Bakar (minyak solar, minyak diesel, dan sebagainya)

Nilai faktor emisi dan nilai kalor bahan bakar dari BBM dibandingkan dengan bahan bakar nabati sebagaimana tertera pada tabel 2 .

Tabel 2.

Faktor emisi dan nilai kalor bahan bakar

\begin{tabular}{|c|c|c|}
\hline \multirow{2}{*}{ Bahan Bakar } & Faktor Emisi CO2 & Nilai Kalor \\
\cline { 2 - 3 } & $(\mathrm{Kg} / \mathrm{TJ})$ & $(\mathrm{TJ} / \mathrm{Gg})$ \\
\hline Bensin & 69.300 & 44,3 \\
\hline Minyak Solar/Diesel & 74.100 & 43,0 \\
\hline LPG & 63.100 & 47,3 \\
\hline Minyak Tanah & 71.900 & 43,8 \\
\hline Pelumas & 73.300 & 40,2 \\
\hline Biodiesel & 70.800 & 27,0 \\
\hline Bieoetanol & 70.800 & 27,0 \\
\hline BBN Lainnya & 79.600 & 27,4 \\
\hline \multicolumn{3}{|c|}{ Sumber: Data primer }
\end{tabular}

Sedangkan potensi pengurangan emisi $\mathrm{CO}_{2}$ dari penggunaan bahan bakar nabati sebagaimana tertera pada tabel .

Tabel 3.

Potensi pengurangan emisi $\mathrm{CO}_{2}$ dari penggunaan biodiesel

\begin{tabular}{|c|c|c|c|}
\hline Parameter & Unit/Tahun & Jangka Menengah & Jangka Panjang \\
\cline { 3 - 4 } & & $\mathbf{( 2 0 1 0 - 2 0 1 5 )}$ & $\mathbf{( 2 0 1 5 - 2 0 2 5 )}$ \\
\hline Substitusi Minyak Solar & Ton minyak & 6.000 .000 & 16.000 .000 \\
\hline Pengurangan Emisi CO2 & Juta ton & 19,12 & 50,98 \\
\hline
\end{tabular}

Sumber: Data Primer 


\section{Penerapan produksi bersih pada industri}

Produksi bersih menurut Kementerian Lingkungan Hidup didefinisikan sebagai strategi pengelolaan lingkungan yang bersifat preventif, terpadu dan diterapkan secara terus-menerus pada setiap kegiatan mulai dari hulu ke hilir yang terkait dengan proses produksi, produk dan jasa untuk meningkatkan efisiensi penggunaan sumberdaya alam, mencegah terjadinya pencemaran lingkungan dan mengurangi terbentuknya limbah pada sumbernya sehingga dapat meminimisasi resiko terhadap kesehatan dan keselamatan manusia serta kerusakan lingkungan (KLH , 2003).

Dari pengertian mengenai produksi bersih maka terdapat kata kunci yang dipakai untuk pengelolaan lingkungan yaitu pencegahan pencemaran, proses, produk, jasa, peningkatan efisiensi, minimisasi resiko. Dengan demikian maka perlu perubahan sikap, manajemen yang bertanggung-jawab pada lingkungan dan evalusi teknologi yang dipilih. Pada proses industri, produksi bersih berarti meningkatkan efisiensi pemakaian bahan baku, energi, mencegah atau mengganti penggunaan bahanbahan berbahaya dan beracun, mengurangi jumlah dan tingkat racun semua emisi dan limbah sebelum meninggalkan proses.

Pola produksi bersih bertujuan untuk mengurangi dampak lingkungan selama daur hidup produk, mulai dari pengambilan bahan baku sampai ke pembuangan akhir setelah produk tersebut tidak digunakan. Produksi bersih pada sektor jasa adalah memadukan pertimbangan lingkungan ke dalam perancangan dan layanan jasa. Penerapan Produksi Bersih sangat luas mulai dari kegiatan pengambilan bahan termasuk pertambangan, proses produksi, pertanian, perikanan, pariwisata, perhubungan, konservasi energi, rumah sakit, rumah makan, perhotelan, sampai pada sistem informasi (Purwanto, 2004).

Pola pendekatan produksi bersih dalam melakukan pencegahan dan pengurangan limbah yaitu dengan strategi 1E4R (Elimination, Reduce, Reuse, Recycle, Recovery/Reclaim) (UNEP, 1999). Prinsip-prinsip pokok dalam strategi produksi bersih dalam Kebijakan Nasional Produksi Bersih (KLH, 2003) dituangkan dalam 5R (Re-think, Re-use, Reduction, Recovery and Recycle) ( Purwanto, 2005). Yang pertama tahap elimination (pencegahan) adalah upaya untuk mencegah timbulan limbah langsung dari sumbernya, mulai dari bahan baku, proses produksi sampai produk. Yang kedua tahap re-think (berpikir ulang), adalah suatu konsep pemikiaran yang harus dimiliki pada saat awal kegiatan akan beroperasi, dengan implikasi : Perubahan dalam pola produksi dan konsumsi berlaku baik pada proses maupun produk yang dihasilkan, sehingga harus dipahami betul analisis daur hidup produk Upaya produksi bersih tidak dapat berhasil dilaksanakan tanpa adanya perubahan dalam pola pikir, sikap dan tingkah laku dari semua pihak terkait pemerintah, masyarakat maupun kalangan usaha. Tahap ketiga yaitu reduce (pengurangan) adalah upaya untuk menurunkan atau mengurangi timbulan limbah pada sumbernya. Keempat, reuse (pakai ulang/penggunaan kembali) adalah upaya yang memungkinkan suatu limbah dapat digunakan kembali tanpa perlakuan fisika, kimia atau biologi. Kelima, recycle (daur ulang) adalah upaya mendaur ulang limbah untuk memanfaatkan limbah dengan memrosesnya kembali ke proses semula melalui perlakuakn fisika, kimia dan biologi. Terakhir, recovery/reclaim (pungut ulang, ambil ulang) adalah upaya mengambil bahanbahan yang masih mempunyai nilai ekonomi tinggi dari suatu limbah, kemudian dikembalikan ke dalam proses produksi dengan atau tanpa perlakuakn fisika, kimia dan biologi.

Menurut Djajadiningrat (2004) penerapan proses recycling dan re-uses yang dilakukan oleh industri Kalundborg ternyata lebih menghemat biaya, mengurangi emisi udara seperti $\mathrm{CO}_{2}$ turun 130.000 ton/th; $\mathrm{SO}_{2}$ turun 25.000ton/th; Sulfur turun 2.800 ton/th; fly ash turun 135.000 ton/th. Hal ini diakibatkan efisiensi dalam penggunaan batubara dan minyak.

\section{Simpulan}

Indonesia sebagai negara berkembang membutuhkan pertumbuhan pendapatan sektor industri. Karena diharapkan sektor industri mendapat nilai tambah yang lebih tinggi dari pada sektor minyak dan gas bumi. Untuk tujuan ini pemerintah RI menarik semua investor baik dari dalam maupun dari luar negeri 
yang mau menginvestasikan modalnya di Indonesia dengan jalan memberikan insentif. Untuk memenuhi standar internasional bagi lingkungan, Indonesia menggunakan GHG Emission Standard yang mengikuti IPCC (Intergovernmental Panel on Climate Change) guidelines. Dalam mengaplikasikan standar tersebut pada industri baja,kimia,aluminium dan semen di Indonesia mempunyai dua pilihan yaitu : pertama menggantikan teknologi lama dengan teknologi baru yang emisi GRK nya kecil, kedua memodifikasi atau menambah peralatan yang mengurangi emisi GRK. Jenis kerjasama yang sesuai untuk empat jenis industri (kimia, baja, semen dan aluminium) adalah model komplementer, yaitu dua kesepakatan simultan yang saling melengkapi.Satu kesepakatan, merupakan kesepakan komprehensif atau global yang meliputi semua sektor sumber emisi, sedangkan kesepakatan yang lainnya bersifat melengkapi bisa merupakan perjanjian spesifik (sektoral) yang berfungsi menyempurnakan kesepakatan global tersebut. Lebih lanjut, berbagai kesepakatan antar negara tersebut dapat dilakukan melalui berbagai mekanisme.

Dalam Protocol Kyoto, tersedia tiga mekanisme fleksibel dalam upaya pencapaian target penurunan emisi GRK, yaitu Emissions Trading (ET) atau perdagangan emisi antar negara maju, Joint Implementation (JI) atau pelaksanaan penurunan emisi secara bersama sama antar negara maju, dan Clean Development Mechanism (CDM) atau kerjasama antara negara maju dan negara berkembang. Pemanfaatan Bahan Bakar Nabati atau biofuel atau green energy sebagai sumber energi yang dapat diperbaharui dapat merupakan salah satu pilihan untuk membantu mengatasi besarnya tekanan kebutuhan energi terutama minyak diesel dan minyak solar. Di samping itu perlu disadari pentingnya proses industri dan 'produksi bersih', karena hal ini dapat meningkatkan efisiensi pemakaian bahan baku, energi, mencegah atau mengganti penggunaan bahan-bahan berbahaya dan beracun, mengurangi jumlah dan tingkat racun semua emisi dan limbah sebelum meninggalkan proses. Produksi bersih pada intinya bertujuan untuk mengurangi dampak lingkungan selama daur hidup produk, mulai dari pengambilan bahan baku sampai ke pembuangan akhir setelah produk tersebut tidak digunakan. Akhirnya, partisipasi masyarakat, industriawan, dan pemerintah secara bersama diperlukan karena merupakan langkah yang paling efektif dalam mitigasi efek GRK.

\section{Daftar Pustaka}

Al-Tuwaijri SA, TE Christensen \& KE Hughes II (2004) The Relations among Environmental Disclosure, Environmental Performance, and Economic Performance: A Simultaneous Equations Approach. Accounting, Organizations and Society, 29 (5-6)447-471.

Bradley R, Baumert K, Childs B, Herzog T \& Pershing J (2007) Slicing the Pie: sector -based approaches to international climate agreements, issues and options, WRI Report.

Choi BB, D Lee \& J Psaros (2013) An Analysis of Australian Company Carbon Emission Disclosure. Pacific Accounting Review, 25(1)58-79.

Clarkson PM, Y Li, GD Richardson \& FP Vasvari (2011) Does It Really Pay to be Green? Determinants and Consequences of Proactive Environmental Strategies. Journal of Accounting Public Policy, 30(2)122-144.

Djajadiningrat \& Surna T (2004) Kawasan Industri Berwawasan Lingkungan. Penerbit Rekayasa Sains, Bandung.

IPCC (2001) Climate Change: The Scientific Basis. Contribution of Working Group I to the Third Assessment Report of the Intergovernmental Panel on Climate Change. Edited by Houghton, J.T. et al. Cambridge University Press: Cambridge. UK.

IPCC (2007) Climate Change: The Physical Science Basis. Contribution of Working Group I to the Fourth Assessment Report of the Intergovernmental Panel on Climate Change. Edited by Alley, R. et al. IPCC Secretariat. Switzerland.

IPCC (Intergovenrmental Panel on Climate Change) Climate Change: The Physical Science Basis. Summary for Policy Makers, Contribution of Working Group I to the Fourth Assessment Report of the Intergovenrmental Panel on Climate Change. Paris, February 2007. http://www.ipcc.ch/, 2007. 
June T (2007) Perubahan Iklim dan Lingkungan. Dalam: Bahan Kuliah Perubahan Lingkungan Global (PSL 706) Program Studi Ilmu Pengelolaan Sumberdaya Alam dan Lingkungan, Sekolah Pascasarjana, Institut Pertanian Bogor. Bogor.

Jannah R \& D Muid (2014) Analisis FaktorFaktor yang Mempengaruhi Carbon Emission Disclosure pada Perusahaan di Indonesia (Studi Empiris pada Perusahaan yang Terdaftar di Bursa Efek Indonesia Periode 2010-2012). Diponegoro Journal of Accounting, 3(2) 111.

Klassen RD \& CP McLaughlin (1996) The Impact of Environmental Management on Firm Performance. Management Science, 42(8)1199-1214.

Krishnan GV (2003) Audit Quality and the Pricing of Discretionary Accruals. Auditing: A Journal of Practice \& Theory, 22 (1)109-126.

Luo L, Q Tang \& Y Lan (2013) Comparison of Propensity for Carbon Disclosure between Developing and Developed Countries: A Resource Constraint Perspective. Accounting Research Journal, 26(1)6-34.

Luo L \& Q Tang (2014) Does Voluntary Carbon Disclosure Reflect Underlying Carbon Performance? Journal of Contemporary Accounting \& Economics, 10(3)191-205.

Matsumura EM, R Prakash \& SC Vera-Munoz (2014) Firm-Value Effects of Carbon Emissions and Carbon Disclosures. The Accounting Review, 89 (2), 695-724.

Najah MSM (2012) Carbon Risk Management, Carbon Disclosure and Stock Market Effects: An International Perspective. Thesis, University of Southern Queensland.

Murdiyarso \& Daniel (2007) CDM: Mekanisme Pembangunan Bersih. Jakarta: Penerbit Buku Kompas.

Noordwijk MV (2008) World Agroforestry Centre, ICRAF-Southeast Asia. Dalam: United Nations Environmental Program, www.unep.org.

Purwanto (2004) Model of Implementation of Cleaner Production in the Small Medium Industries, Nasional Seminar on Chemical and Process VI, 23 Maret, Jakarta.

Purwanto (2005) Implementation of Cleaner Production in the Electroplating Small Medium Industries, Regional Symposium on Natural Resources, March, Kuala Lumpur

Panjiwibowo dkk (2008) Mencari Pohon Uang: CDM di Indonesia. Jakarta: Pelangi.

Sugiyono A (2008) Seminar Nasional Kebijakan Pemanfaatan Lahan dalam Menanggulangi Dampak Pemanasan Global, Keluarga Mahasiswa Ilmu Tanah, Fakultas Pertanian, UGM, Yogjakarta 10 Mei 2008.

Suara K (2007) Kesadaran Industri Mengenai Pengenalan Limbah Masih Rendah, 2 April 2007. 